\title{
Adult's perception of health care after myocardial infarction
}

\author{
Percepção do cuidado à saúde de adultos após o infarto do miocárdio \\ Percepción del cuidado a la salud de adultos después del infarto de miocardio
}

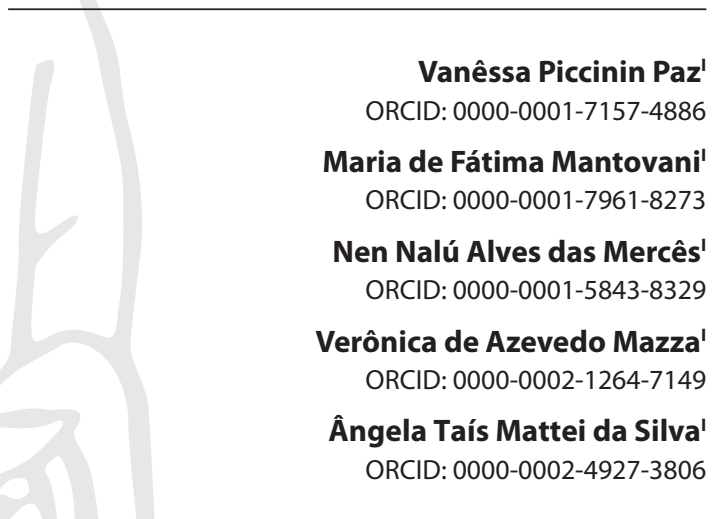

'Universidade Federal do Paraná. Curitiba, Paraná, Brazil.

How to cite this article:

Paz VP, Mantovani MF, Mercês NNA, Mazza VA,

Silva ATM. Adult's perception of health care after myocardial infarction. Rev Bras Enferm. 2020;73(5):e20190074. doi: http://dx.doi.org/10.1590/0034-7167-2019-0074

\section{Corresponding author:}

Vanêssa Piccinin Paz

E-mail: vanessa.piccinin7@gmail.com

EDITOR IN CHIEF: Antonio José de Almeida Filho ASSOCIATE EDITOR: Priscilla Valladares Broca

Submission: 03-15-2019

Approval: 11-11-2019

\begin{abstract}
Objectives: to describe the Adult's perception of healthcare after Myocardium Infarction. Methods: qualitative descriptive analysis carried out with 12 adults who had myocardial infarction and conducted from February to May 2018. The research design was based on the "Consolidated Criteria for Reporting Qualitative Research". Data collection was performed through semi-structured questionnaire, interview script and field diary. The interviews were encoded, and their content was analyzed using software support. Results: three classes were obtained: "Fear, (un) certainty and (un) awareness"; "Lifestyle and beliefs of illness" and "Health care search". Unhealthy lifestyle habits, lack of health prevention / promotion, difficulties in accessing services and lack of knowledge about the disease generated fear and uncertainty about the future. Final Considerations: the perception of acute myocardial infarction is related to the trajectory of illness, lifestyle and the belief that the infarction only affects others. Descriptors: Chronic Disease; Myocardial Infarction; Adult Health; Perception; Community Health Nursing.
\end{abstract}

\section{RESUMO}

Objetivos: das percepções do cuidado à saúde de adultos após o infarto do miocárdio. Métodos: pesquisa qualitativa descritiva analítica realizada com 12 adultos que tiveram infarto do miocárdio, de fevereiro a maio de 2018. O desenho baseou-se no "Consolidated Criteria for Reporting Qualitative Research". A coleta de dados foi realizada mediante questionário semiestruturado, roteiro de entrevista e diário de campo. As entrevistas foram codificadas, e seu conteúdo foi analisado com auxílio de software. Resultado: obtiveram-se três classes: "Medo, (in) certeza e (des)conhecimento"; "Estilo de vida e crenças do adoecimento"e "Busca pelo cuidado de saúde". Os hábitos de vida não saudáveis, a falta de prevenção/promoção da saúde, as dificuldades de acesso aos serviços e o desconhecimento da doença geraram medo e incerteza quanto ao futuro. Considerações Finais: a percepção do infarto agudo se relaciona com a trajetória do adoecimento, estilo de vida e crença de que o infarto só acomete o outro.

Descritores: Doença Crônica; Infarto do Miocárdio; Saúde do Adulto; Percepção; Enfermagem em Saúde Comunitária.

\section{RESUMEN}

Objetivos: describir las percepciones del cuidado a la salud de adultos después del infarto de miocardio. Métodos: investigación cualitativa descriptiva analítica realizada de febrero a mayo de 2018 con 12 adultos que tuvieron infarto de miocardio. El dibujo ha sido basado en el "Consolidated Criteria for Reporting Qualitative Research". La recogida de datos ha sido realizada mediante cuestionario semiestructurado, guion de entrevista y diario de campo. Las entrevistas han sido codificadas, y su contenido ha sido analizado con auxilio de software. Resultados: se obtuvieron tres clases: "Medo, duda y (des)conocimiento"; "Estilo de vida y creencias de enfermedad" y "Búsqueda por el cuidado de salud". Los hábitos de vida no saludables, la falta de prevención/promoción de la salud, las dificultades de acceso a los servicios y el desconocimiento de la enfermedad generaron medo y duda cuanto al futuro. Consideraciones Finales: la percepción del infarto agudo relacionase con la trayectoria de la enfermedad, estilo de vida y creencia de que el infarto solo acomete al otro.

Descriptores: Enfermedad Crónica; Infarto de Miocardio; Salud del Adulto; Percepción; Enfermería en Salud Comunitaria. 


\section{INTRODUCTION}

The process that culminates in a myocardial infarction (AMI) occurs slowly and silently, as coronary artery disease develops gradually over the years, so people have difficulty identifying and interpreting that there is something "wrong" with their body ${ }^{(1)}$.

It is possible to characterized infarction as a deficiency in the blood supply to the vessels and arteries of the heart, causing failure in cardiac function and various health complications in people who are affected, especially young adults(2).

There is no doubt that daily living habits can have profound effects on the likelihood of developing cardiovascular disease. Among the risks described, we can classify them as non-modifiable, such as family history, gender and advanced age; and the modifiable ones being smoking, sedentarism, alcohol intake, obesity and overweight, as well as psychological stress ${ }^{(3)}$.

When the acute cardiac event occurs, people are frightened and surprised because they were not prepared to fall ill and were often performing their routine activities. After AMI, because they are young and consider themselves healthy, feelings of fear of death, disability and the unknown arise. In this new phase, they need to learn to cope with the dependence caused by the disease and the need for ongoing care ${ }^{(4-5)}$.

The illness caused by AMI changes the life of both the affected person and their relatives, by modifying the routine due to the absence of work activities and generating physical limitations on the person who fell ill. At this point, the importance of a structured family network to assist in home care arises ${ }^{(6)}$.

It can be considered that the search for health care performed by the people who suffered the infarct is related to the way they experience and understand the disease and how much getting sick impacts their life routine ${ }^{(7-8)}$.

Health and disease arise from the interaction between the biological and the environment in which the person lives, whether it is the society or the community in which they are inserted. Therefore, the way they come to understand the disease cannot be characterized solely as a biological event, but a process of experiences. In it, for each person, there is an individual meaning about what is "being sick", which is built by their cultural and social values, in a dynamic way, which leads to various questions by the person affected by the cardiac event, in the work with my family and health team to find a cure ${ }^{(9)}$.

Thus, there is a need to describe how people perceive myocardial infarction and how the cardiac event interferes with their lives.

\section{OBJECTIVES}

To describe the Adult's perception of healthcare after Myocardium Infarction.

\section{METHODS}

\section{Ethical aspects}

The study was submitted to the Ethics Committee of the state of Paraná, and the recommendations of Resolution 466/2012 of the National Health Council (CNS) were followed, with CAAE No.
82916018.9.0000.0107 and approval opinion 3,178,581. To carry out the study, we obtained the authorization from the Health Department of the city (Secretaria Municipal de Saúde) where the study was conducted. All participants signed the free and informed consent form. After the full transcript of the interview content, a copy was given to the participant for prior reading of the material and confirmation or rectification of some excerpt read. The information collected was kept anonymous, and the participant's name was replaced by an identifying code, using the letters IP (interview / participant) followed by an Arabic number in ascending order (IP_1, IP_2...). The research was conducted at the participant's home, in a private place, without the presence of other people, except in cases where the participant requested it.

\section{Type of study}

This is a qualitative descriptive analytical study, derived from a master's thesis. The Consolidated Criteria for Reporting Qualitative Research (COREQ) was used as the basis for the study.

\section{Methodological procedure}

The study included 12 adults of both sexes, aged 18 to 65 years, who were affected by AMI, from February to May 2018. The inclusion criteria were having a diagnosis of AMI in medical records, having confirmation by family member or participant, living in the municipality where the research was being carried out, having been attended in an emergency room and transferred to the standard cardiology hospital. For exclusion, the Mini-Mental State Exam (MMSE) was used, the cut point being 13 for illiterate, 18 for low and medium education and 26 for high education. 1 to 4 years are considered as low education level; average schooling, from 4 to 8 incomplete years; and high education, over 8 years ${ }^{(10)}$.

\section{Study Scenario and Data Source}

The research was conducted in a city located in the western region of the state of Paraná. To list the participants who could be part of the research, the main researcher daily checked the list of hospitalization and transfer of the Medical File Service sector (SAME) of the Emergency Care Units of the municipality. After identifying the possible participants by the diagnostic obtained from the online ambulatory care form, a telephone contact was made and a home visit was scheduled to present the research project, at a place, date and time defined by the participants or their relatives.

\section{Data collection and organization}

For data collection, we used a semi-structured form that included the sociodemographic, clinical, and lifestyle habits variables of the participants. There was also an interview script with ten open questions and a field diary, in which aspects of the participant's environment, family interaction, and verbal and nonverbal answers were noted.

The researcher recorded the interviews, with the prior consent of the interviewees and lasted an average of one hour. After transcribing and reading all the interviews, we used as support 
for content analysis and data encoding the software Interface de R pour les Analyses Multidimensionnelles de Textes et de Questionnaires (IRAMUTEQ_0.6-alpha3 $3^{\circ}$ ). The characterization of the participants was presented through tables and analyzed using descriptive statistics with the aid of Microsoft Excel ${ }^{\circ}$ 2010. For lexical analysis, IRAMUTEQ_0.6-alpha3 ${ }^{\circ}$ was used.

\section{Data Analysis}

The content analysis of the statements was performed according to the steps proposed by Creswell(11), by the following steps: 1 ) pre-analysis; 2) material exploration or encoding and treatment of results; and 3) interpretation. In the first stage, the interviews were organized and transformed into text units to explore the content by transcribing it and reading the interviews word for word. The field diary was used to complement the information, emphasizing the different phases experienced by people by AMI, chronologically. The reading of the participants' reports aimed to understand them and further fragment and construct the textual corpus for insertion in the IRAMUTEQ_0.6-alpha3 ${ }^{\circ}$ qualitative analysis software.

This software provides statistical accuracy, allowing the use of various technical vocabulary analysis resources, in which words are grouped and organized graphically according to their frequency, enabling the construction of a single corpus that gathers the texts interview originals ${ }^{(12)}$.

Textual statistics or classical lexical analysis, provided by the software, present the number and segments of text, identify word count, average frequency and hapax (words with a frequency of one), investigate vocabulary, reduce words based on their roots (reduced form) and identify active and supplemental forms. Specificities analysis allows the association of texts with variables characterization of the text narrators. ${ }^{(12-13)}$. For the construction of the analysis corpus, the texts were recorded in the format "txt" and encoded in Unicode UTF $8^{(12)}$.

In the second stage, exploring or encoding the material, the interviews were described in sequence, and the text was separated into smaller categories of information, allowing an accurate description of the relevant properties of the presented content. The corresponding classes identified were named using the software ${ }^{(11)}$.

In the third stage, the speech was interpreted and analyzed, expanding the meanings of the codes and themes found beyond the initial representation. The interpretation and understanding of the data were performed based on the research literature.

\section{RESULTS}

The transcripts of the interviews allowed a general corpus consisting of 12 texts, separated into 226 text segments (TS) with $81.42 \%$ utilization. The first category originated from the subcorpus of classes 1 and 6, with 23 Elementary Context Units (ECUs) and 31 ECUs, corresponding to $12.5 \%$ and $16.85 \%$, respectively. The second category was formed by the subcorpus of classes 2 and 3, both with 29 ECUs, equivalent to $15.76 \%$. And the third category corresponds to classes 4 and 5, with 38 and 34 of the ECUs, concentrating $20.65 \%$ and $18.48 \%$ of the total corpus ECUs, respectively. These classes were organized by similarity into three categories: "Fear, (un) certainty and (un) awareness"; "Lifestyle and beliefs of illness" and "Health care search".

Participants were 4 women and 8 men, aged from 36 to 65 years; having an income higher than 2 minimum wages, married or in a stable union, with less than 3 children. Two participants were not literate. Regarding lifestyle, eight participants, before AMI, consumed alcohol, two smoked and all did not practice physical activities regularly.

Regarding the presence of comorbidities, five had hypertension, one was diabetic, and the others were unaware of any associated pathology, but had a family history of cardiovascular disease. The Brazilian National Health System (SUS - Sistema Único de Saúde) was the first choice in the search for health care, but they migrated to private service to complement care.

In the first category, "Lifestyle and beliefs of illness", it is clear that the participants' lifestyle reflects their family history. Stress and anxiety, related to the modern lifestyle, agitation and, daily rush, were considered as important causes of illness and responsible for the acquirement of unhealthy lifestyle habits.

[...] / consider as a risk factor the day-to-day rush, a lot of stress... I am very stressed and nervous; this was my biggest problem. I was fighting for anything, I was stressed out with other people's lives, I wanted to solve other people's problems, which had nothing to do with me. Infarction results from this process. (IP_2)

Before discovering high blood pressure, it was normal. I ate a lot, smoked and drank. After I found out the high blood pressure, I changed my habits. I don't think smoking and drinking are good, but I don't think that was it, because I didn't drink that long, maybe the diet. (IP_3)

[...] risk factors I don't think I took care of myself, I used to abuse fatty foods and salt foods and that's where it happened. Barbecue, we ate it a lot, my father cooked pork, there always was meat. (IP_6)

At that time, I lived on the farm, in the country and I used to eat everything. Every food was salty, I remember my mother even used to drink salted milk, but everything was normal [...]. (IP_8)

In the second category, "(Un) awareness, Fear and (Un) Uncertainty", the statements revealed questions about illness, fear and uncertainties regarding the future, as well as ignorance of the precipitating factors of AMI.

The perception of the disease repercussions demonstrates that the participants did not perform ongoing health care, which is evidenced by aspects such as inadequate lifestyle, lack of adherence to drug treatment, lack of concern with health prevention and promotion, lack of knowledge about the disease and, the changes caused by the infarction in their lives.

Now It's about taking care of me. This week I didn't open the bar not even one day, if I feel like it, I'll open it. I won't stress out, but before, I was very stressed out if I didn't open the bar, God forbid! It was really stressing. [...]. About the diet, especially, I'm taking care of myself. I made an appointment with a nutritionist, I have to take care of myself, God forbid. In the future, I hope to treat me myself like a prince, taking care of myself, going to the doctor, making clinical exams. (IP_2) 
The blood pressure always fluctuates, if l eat anything a bit salty, it already changes it. I never worried about health, when I was young my life was working, I left early and came back at night. We never played in our childhood, always working. (IP_6)

In my family, my wife takes medicine and goes to the doctor. Before the heart attack, I was not afraid of anything and I was not scared of anything, but I was really scared. After the heart attack, a lot has changed, and I think a little differently. My biggest problem is the cigarette. (IP_11)

[...] I didn't know much, that my heart had an injury ... I thought it was just a clogged vein. You can carry on your normal life, so I can carry on my normal life, but I have one limitation now that is to take medicine. I hate taking medicine, but I have to. (IP_12)

In the category "Search for health care", it was possible to perceive the barriers the participants encountered during the search for care in the health sector, such as the delay in care, the difficulty in early identification of $\mathrm{AMI}$, the professionals lack of reception and willingness to help.

lasked to call the emergency service because I was having a heart attack, it was bad... it was sudden. They measured my blood pressure and it was normal, but I was in great pain. I said I wasn't feeling good, but They didn't want to take me to emergency, so I called my brother-in-law who took me to the emergency. (IP_2)

I went alone to the health center at dawn to get a number in the line and I couldn't. The second time, the other day, I went earlier, and I got it. The pain was already unbearable; I couldn't take it anymore: it started in the throat and went down to the middle of the chest. It was terrible. (IP_4)

I was worried. I think it's something serious. So, I went by motorcycle to the emergency unit, where they measured my blood pressure and told me to wait. I waited from 4 am to 9 am to be attended; and the pain was getting stronger. I was almost crying. (IP_11)

\section{DISCUSSION}

The participants' reports showed their perceptions about AMI, through which it was possible to highlight the lack of interest characterized by negligence regarding health care, lack of selfcare and, the perspective that the disease only affects the other.

This perception may be linked to the fact that AMI suddenly sets in and determines difficult and painful changes in the health status of people who did not expect to get sick or have their lives changed due to illness. Besides, the acute infarction generates feelings of uncertainty about the future, doubts, and fears regarding the treatment and severity of the disease, and also the therapeutic procedures. They lead the affected person to reflect on the possibility of leaving their relatives without support, as well as on their finitude ${ }^{(5)}$.

Ignorance regarding the process of illness interferes with adherence to treatment, as it is influenced by beliefs and myths experienced by people throughout their lives and can generate demotivation to control the disease, inability to relate the behavior with the management of adverse situations and low expectation in the result of treatment ${ }^{(14)}$.
People's attitudes represent the way they think and how they feel about the disease, based on life experience, which influences their way of acting or behaving in the face of certain situations. The worldview acquired throughout life impacts on decision making and it is represented in the different behaviors people present in their illness ${ }^{(15)}$.

The cardiac event triggers a stressful effect on the patients and their family, as it generates fear that the affected person will have a new occurrence. After AMI, in most cases, a caregiver appears within the family network for monitoring and controlling the patients'life so that they do not get sick again because the family believes that the resistance to treatment is the cause of the disease ${ }^{(16)}$.

Regarding lifestyle and beliefs of illness, participants recognized that unhealthy habits, especially regarding diet, stress and, anxiety, contributed to the occurrence of AMI. The illness understanding relates to the patients' beliefs regarding why it occurs. In most cases, they relate it to food, family heritage and, problems with the environment, people and society ${ }^{(17)}$.

The participants' reports show the difficulty in the primary identification of cardiac events through the denial of the signs and symptoms severity. This result corroborates a study conducted in Istanbul, Turkey, with 93 patients who suffered infarction. This study made possible to realize that $81.7 \%$ stated that if they were aware or understood that signs and symptoms indicated heart problems, they would have sought pre-hospital care earlier. Furthermore, $33.3 \%$ of patients did not consider their complaints serious and expected them to recover; a total of $45.2 \%$ did not attribute the symptoms to cardiac causes ${ }^{(18)}$.

Another study developed in Sweden, with 21 infarcted men, also found that the delay in seeking specialized medical care was associated with misinterpretation of symptoms, illusion of invulnerability, a belief that symptoms would disappear or attempt to relieve or treat symptoms before seeking specialized care ${ }^{(19)}$.

These studies presented similarities with the present study, in which participants reported difficulties in identifying the cardiac event, resistance in seeking health services at the first moment, denial of severity, fear of loss of control and independence due to illness, tolerance to pain and hope that symptoms would disappear.

After the cardiac event, people perceive that their way of living has been modified, they often present limitations in relation to daily activities and in order to avoid a new episode of infarction or develop other heart disease, they try to modify their lifestyle ${ }^{(20)}$.

Knowledge regarding risk factors for the development of coronary heart disease has a close relationship with the way in which people deal with life, disease and health. A qualitative study conducted with 31 people in a family health unit, after being affected by an $\mathrm{AMI}$, observed that, in relation to the knowledge of the disease, its definition and risk factors for the development of the AMI episode, $15 \%$ could explain the disease, and $74 \%$ of the people interviewed reported only 1 to 2 causes as risk factors. Regarding lifestyle, 58\% did not modify their lifestyle. The study noticed that people still have little information about the disease and its prevention, a fact that contributes to the difficulty in adherence to healthy lifestyle habits ${ }^{(21)}$.

Lifestyle can remain for decades in a family and can lead to the development of the same diseases of that family nucleus because eating habits are elaborated in childhood and can perpetuate generation to generation ${ }^{(17)}$. 
A study conducted in southern Taiwan observed the association between the overweight of parents, diabetes, hypertension and pediatric adiposity in the development of cardiometabolic risk factors among adolescents. The study found that a healthy lifestyle based on the family is important for the prevention of risk factors such as obesity and hyperlipidemia, as shared environments through generations influence the eating habits acquired and reproduced in adulthood ${ }^{(22)}$.

For the treatment of cardiovascular diseases, it is necessary that affected people understand the factors that influence the emergence and development of the diseases, so that they become aware of the importance of a healthy lifestyle to prevent related complications ${ }^{(23)}$.

Knowing the family history is important for the development of actions aimed at preventing and/or delaying the onset of cardiovascular diseases, especially in young adults ${ }^{(24)}$.

Lifestyle-related risk factors, such as eating habits, tobacco and alcohol use, and physical inactivity, are also associated with psychosocial factors, a result of modern life that has intensified stress and consequently generated anxiety and depression. This leads people to develop unhealthy habits that directly affect their health and may trigger heart attack ${ }^{(25-26)}$.

A study conducted in Brazil observed that patients with symptoms of AMI did not immediately seek health services because they had difficulty understanding the initial signs and symptoms. This interfered with the immediate search for professional healthcare ${ }^{(27-28)}$, which this research also observed in the participants' statements.

The delayed recognition of the cardiac event and, consequently, the late search for the health system are the result of the difficulty of patients with AMI in identifying the signs and symptoms related to this episode. Therefore, this interferes with the prognosis, which could be better if they could understand earlier the signs and symptoms presented as an urgency ${ }^{(29)}$.

In addition to the participants having delayed demand for health services, we noticed that when they sought it, they had difficulties to be attended, which was mainly due to the lack of early recognition of AMI signs and symptoms by health professionals, difficulty of reception, denial of care and overcrowding of prehospital care units.

The delay in seeking prehospital care is an important obstacle to the proper management of $\mathrm{AMI}^{(30)}$. When the search for emergency services occurs, people often face overcrowding, the physical structure scrapping, poor and ineffective care, difficulty in early recognition of AMI by professionals, reception difficulties and denial of $\operatorname{care}^{(7,31)}$.

A study conducted in Bahia, in two benchmark hospitals in cardiology, with 100 users who had myocardial infarction, observed that, regarding the conduct of health professionals, $82 \%$ had the expected care, that is, they were treated and admitted or admitted and transferred to other services, and 18\% did not have the expected care, due to the lack of structure of institutions and the difficulty of clinical management by health professionals regarding infarction ${ }^{(32)}$.

This research observed problems in the provision and organization of care to people affected by AMI, a fact that corroborates the lack of public health structure, evidenced by the low supply of clinical and surgical beds in the cardiology specialty, insufficient response from emergency services. This happens because, although these services aim to provide fast care and counter-reference to other sectors of the health network, there are difficulties in the work process, such as overloading the care of spontaneous demand disconnected from basic health units, health teams dislocated, disjointed work process, scrapping of physical structures, and difficulties in reference and counter-reference ${ }^{(33)}$.

It is noteworthy that people's perceptions about the disease have multiple factors, which permeate the physiological, and determine the adherence or not to treatment, such as family habits, life history, and experiences in the search for the health system, which interfere with the way people seek health services.

Thus, professionals must be aware of the patients' needs and develop practical and effective actions for the treatment - whether in the physiological and therapeutic aspects or regarding the limitations and frustrations caused by the illness - through active listening and welcoming, valuing people's core. Studies that evaluate people's perceptions should be carried out in environments outside the health services, so that they can discuss their real perceptions.

\section{Study limitations}

The limitation of this study is that it was performed only in Emergency Care Units and exclusively with people who use public health services. For the search performed in the Emergency Care Units, according to the age group chosen for the research, the number of participants was reduced due to losses related to the complication of the clinical picture, resulting in a sample of 12 participants.

\section{Contributions to the nursing, health, or public policy fields}

The results of this study contribute to a different perspective on the care of adults who suffered infarction. A perception that is not limited to physiological aspects, but that considers care more broadly, like active listening and appreciation of information passed on by people when seeking health services.

\section{FINAL CONSIDERATIONS}

Research participants, through their testimonies, perceive AMI as a consequence of their lifestyle and beliefs of illness, which are related to lifestyle habits, especially eating habits, considered as the main factor for the development of the infarction, so that it becomes the goal of change, because, by modifying it, they would not get sick again.

In the acuity period, we noticed that the search for health care was hindered by ignorance of signs and symptoms, as well as barriers to care access. After AMI, participants reported fear of a new episode, which made them rethink their life and finitude, about the need to take care of their health and to acquire healthier habits, as well as to adhere to drug treatment correct form.

We suggest expanding this research by investigating the comprehension of how health professionals approach people with AMI. 


\section{REFERENCES}

1. American Heart Association (AHA). History of the American Heart Association. AHA [Internet]. @2018[cited 2018 Feb 16]. Available from: https://www.heart.org/en/about-us/history-of-the-american-heart-association

2. Vargas RA, Riegel F, Oliveira Jr N, Siqueira DS, Crosetti, MGO. Quality of Life of Patients after myocardial infarction: literature integrative review. Rev Enferm UFPE. 2017;11(7):2803-9. doi: 10.5205/reuol.10939-97553-1-RV.1107201721

3. Rippe JM, Angelopoulos TJ. Lifestyle strategies for cardiovascular risk reduction. Curr Atheroscler Rep. 2014;16(10):444. doi: 10.1007/s11883-014-0444-y

4. Garcia RP, Budó MLD, Simon BS, Wünsch S, Oliveira SG, Barbosa MS. Family experiences post-acute myocardial infarction. Rev Gaucha Enferm. 2013;34(3):171-8. doi:10.1590/S1983-14472013000300022

5. Vieira MB, Souza WS, Cavalcante PF, Carcalho IGM, Almeida RJ. Men's perception after acute myocardial infarction. Rev Bras Promoç Saúde. 2017;30(3):1-9. doi: 10.5020/18061230.2017.5833

6. Camponogara S, Silveira M, Cielo C. Percepções de pacientes submetidos à cirurgia cardiovascular sobre o adoecimento. Rev Enferm Cent $\mathrm{O}$ Min. 2014;4(1):993-1003. doi:10.19175/recom.v0i0.554

7. Gyberg A, Björck L, Nielsen S, Määttä S, Falk K. Women's help-seeking behavior during a first acute myocardial infarctio. Scand. J Caring Sci. 2016;30(4):670-7. doi: 10.1111 / scs.12286

8. Mussi FC, Mendes AS, Damasceno CA, Gibaut MAM, Guimarães AC, Teles CAS. Fatores ambientais associados ao tempo de decisão para procura de atendimento no infarto do miocárdio. Rev Bras Enferm. 2014;67(5):722-9. doi: 10.1590/0034-7167.2014670508

9. Langdon EJ. Os diálogos da antropologia com a saúde: contribuições para as políticas públicas. Ciên. e Saúde Coletiva. 2014;19(4):1019-29. doi: 10.1590/1413-81232014194.22302013

10. Bertolucci P HF, Brucki SMD, Campacci SR, Juliano Y. et al. O mini-exame do estado mental em uma população geral: impacto da escolaridade. Arq Neuropsiquiatr. 1994;52(1):1-7. doi: 10.1590/S0004-282X1994000100001

11. Creswell JW. Investigação Qualitativa: Projeto de Pesquisa escolhendo entre cinco abordagens. 3. ed. São Paulo: Penso Editora, 2014.

12. Camargo BV, Justo AM. IRAMUTEQ: um software gratuito para análise de dados textuais. Temas psicol. 2013;21(2):513-8. doi: 10.9788/TP2013.2-16.

13. Salviati ME. Manual do Aplicativo Iramuteq: versão 0.7 Alpha 2 e R Versão 3.2.3. [Internet] 2017 [cited 2018 Aug 01];sn. Available form: http:// www.iramuteq.org/documentation/fichiers/anexo-manual-do-aplicativo-iramuteq-par-maria-elisabeth-salviati

14. Barreto MS, Reiners AAO, Marcon SS. Knowledge about hypertension and factors associates with the non-adherence to drug therapy. Rev Latino-Am Enfermagem. 2014;22(3):491-8. doi: 10.1590/0104-1169.3447.2442

15. Coelho AC, Barros ALBL de, Matheus MCC, Domingues TAM. [Beliefs, values and attitudes of cohabiting relatives of coronary artery disease patients]. Rev Min Enferm. 2016;20:e980. doi:10.5935/1415-2762.20160050 Portuguese.

16. Garcia RP, Budó M de LD, Viegas A da C, Cardoso DH, Schwartz E, Muniz RM. Estrutura e vínculos de uma família após infarto agudo do miocárdio. Rev Cuidarte. 2015;6(1):991-8. doi: 10.15649/cuidarte.v6i1.142

17. Bankoff ADP, Arruda M de, Bispo IMGP, Rodrigues MD. Doenças crônicas não transmissíveis: história familiar, hábitos alimentares e sedentarismo em alunos de graduação de ambos os sexos. Revista Saúde e Meio Ambiente - RESMA, [Internet] 2017 [cited 2018 Aug 11];5(2):37-56. Available from: http://seer.ufms.br/index.php/sameamb/article/view/4246/pdf_26

18. Koc S, Durna Z, Akin S. Interpretation of symptoms as a cause of delays in patients with acute myocardial infarction, Istanbul, Turkey. East Mediterr Health J[Internet]. 2017 [cited 2018 Sep 10];23(4):287-97. Available from: https://www.ncbi.nlm.nih.gov/pubmed/28634979

19. Nielsen S, Falk K, Gyberg A. et al. Experiences and Actions During the Decision Making process among Men with a first acute myocardial infarction. J Cardiovasc Nurs. 2015;30(4):332-9. doi: 10.1097/JCN.0000000000000137

20. Nunes S, Rego G, Nunes R. Difficulties of Portuguese patients following acute myocardial infarction: Predictors of readmissions and unchanged lifestyles. Asian Nursing Research. 2016;10(2016)150-7. doi: 10.1016/j.anr.2016.03.005

21. Oliveira LB, Püschel VAA. [Knowledge on disease and lifestyle changes in patients post-infarction]. Rev Eletr Enferm. 2013;15(4):1026-33. doi: 10.5216/ree.v15i4.18442 Portuguese.

22. Lee, C-Y, Lin W-T, Tsai S, Hung YC, Wu PW, Yang YC, et al. Association of Parental Overweight and cardiometabolic diseases and pediatric adiposity and lifestyle factors with cardiovascular risk factor clustering in adolescents. Nutrients. 2016; 8(9).piiE567. doi: 10.3390/nu8090567

23. Knebel IL, Marin AH. Fatores psicossociais associados à doença cardíaca e manejo clínico psicológico: percepção de psicólogos e pacientes. Rev SBPH (Sociedade Brasileira Psicologia Hospitalar). [Internet] 2018 [cited 2018 Oct 28];21(1). Available from: http://pepsic.bvsalud.org/ $\mathrm{pdf} / \mathrm{rsbph} / \mathrm{v} 21 \mathrm{n} 1 / \mathrm{v} 21 \mathrm{n} 1 \mathrm{a} 07 . \mathrm{pdf}$

24. Mauricio TF, Moreira RP, Costa EC, Bernardo FMS, Lima PAL, Viegas BJ. [Evaluation of the presence of cardiovascular risk factors in university students from portuguese-speaking countries]. Cogitare Enferm. 2018; (23)3:e55216. doi:10.5380/ce.v23i3.55216 Portuguese.

25. Araújo MCF, Alves MS, Padre PMM, Andrade DM, Silva ACMS, Baretto LP, et al. Perfil de Não adesão ao tratamento de usuários com diabetes e hipertensão em uma unidade de Saúde da família. Ensaios Cienc Biol Agrar Saúde[Internet] 2016 [cited 2017 Dec 06];20(1):43-48. Available form: http://pgsskroton.com.br/seer/index.php/ensaioeciencia/article/view/3851 
26. Gomes CM, Capellari C, Pereira D dos SG, Volkart PR, Moraes AP, Jardim V, et al. Stress and cardiovascular risk: multi-professional intervention in health education. Rev Bras Enferm. 2016;69(2):329-36. doi: 10.1590/0034-7167.2016690219i

27. Santos AAA, Braz DDS, Cavalcante AB, Trindade LS, Barros AMMS, Souza DS. Identificação precoce da síndrome coronariana aguda: uma revisão bibliográfica. Ciênc Biol Saúde Unit [Internet]. 2017 [cited 2018 Feb 05];4(2):219-36. Available from: https://periodicos.set.edu.br/ index.php/cadernobiologicas/article/view/4609.

28. Bastos AS, Beccaria LM, Contrin LM, Cesarino CB. [Time of arrival of patients with acute myocardial infarction to the emergency department]. Rev Bras Cir Cardiovasc. 2012; 27(3)411-418. doi: 10.5935/1678-9741.20120070 Portuguese.

29. Tummala SR, Farshid A. Patients' understanding of their heart attack and the impact of exposure to a media campaign on pre-hospital time. Heart, Lung Circulat. 2015;24(1):4-10. doi: 10.1016/j.hlc.2014.07.063

30. Li PWC, Yu DSF. Predictors of pre-hospital delay in Hon Kong Chinese patients with acute myocardial infarction. Eur J Cardiovasc Nurs. 2018; 17(1):75-84. doi: 10.1177 / 1474515117718914.

31. Ammouri AA, Kamanyire JK, Abu Raddaha AH, Achora S, Obeidat AA. Another chance at life: Jordanian patients' experience of going through a myocardial infarction. Rev Theor Nurs Pract. 2017;31 (4: 334-348. doi: 10.1891 / 1541-6577.31.4.334

32. Mendes AS, Reis VRSS, Menezes TMO, Santos CAST, Mussi FC. Access of patients with myocardial infarction to cardiology reference hospitals. Acta Paul Enferm. 2014;27(6):505-12. doi:10.1590/1982- 0194201400083

33. Mendes AS, Reis VRSS, Santos CAST, Mussi FC. Access times to health services in cases of myocardial infarction. Acta Paul Enferm. 2016;29(4):446-53. doi:10.1590/1982-0194201600061 